\title{
Introduction
}

\section{Reclaiming Democracy and Social Justice: The Arab Spring, Occupy, and Radical Imaginaries in the $21^{\text {st }}$ Century}

\author{
TANYA BASOK \\ University of Windsor, Canada
}

In the last few years we have witnessed a wave of mass protests against authoritarianism, corporate monopoly, privatizations, and the decline of social protections. The uprisings against neoliberal policies and corrupt, authoritarian and repressive governments in Egypt, Tunisia, Libya, and Syria, coined the "Arab Spring," have inspired other similar forms of activism such as: the occupation of the Wisconsin statehouse by the organized labour movement and their supporters; teachers' strikes in Chicago; rallies against economic austerity measures in Madrid and other Spanish cities organized by the indignados; protests against economic injustice in Athens and Tel Aviv; the YoSoy132 movement in Mexico; the mass mobilizations in New York against global economic injustice known as Occupy Wall Street; followed shortly by a plethora of other Occupy movements in North America, Europe and elsewhere; and, a wave of student protests in Quebec, Canada.

Using the metaphor of " $1 \%$ versus $99 \%$," these various movements have questioned the global economic order that has resulted in wide disparities in economic wealth and political power. Employing the model of consensus decision-making, these movements have attempted to establish alternative models of grassroots democracy that Michael Hardt and Antonio Negri (2005) have described as the "multitude form." Now, almost three years after the Occupy camps sprung up, it is important to explore the impact of these movements. More specifically, it would be pertinent to ask the following questions. To what degree have these resistance movements advanced new languages, metaphors, and imaginaries of social struggle? How similar or 
different are these movements from earlier forms of social unrest? How inclusive have these movements been of diverse voices of protest? How has the consensus model of decision making worked in practice? Have there been any practical achievements? What has happened to the Occupy movement once the camps closed down? What has been the impact of these mobilizations on the participants? What is the future of global resistance?

These questions relate to many issues that have been debated by social movement theorists in the past several decades. Scholars like Alberto Melucci, Charles Tilly, Doug McAdam, Sydney Tarrow, Jackie Smith and others have raised important questions concerning social movements. Do post-modern social activists aim to bring about political change or foment new identities, social relations, and life styles (e.g. Melucci, 1989; Buechler, 2000)? Are they more likely to succeed when "political opportunities structures" are more open (e.g. McAdam, McCarthy, \& Zald, 1999)? How do they address issues of gender, class, racial, and other diversities (e.g. M. Smith, 2008)? What impact has globalization had on various forms of protest (J. Smith \& Johnston, 2002)? Are transnational forms of activism more effective (Tarrow, 2005; J. Smith, 2008; Routledge \& Cumbers, 2009)? How do social movements articulate new visions of democracy and equality (Hardt \& Negri, 2005)? What is the importance of the cognitive frames they advance (Snow $\&$ Benford, 2000)? The recent wave of activism compels social movement scholars to revisit some of the old question and pose new ones.

On May 17 and 18, 2013, a workshop exploring these and other issues was held at the University of Windsor. This international workshop was organized by the Editors of Studies in Social Justice with the support of the University of Windsor's now-closed Centre for Studies in Social Justice and funded in part by the Social Sciences and Humanities Research Council of Canada. Coming from different regions and academic disciplines, twenty-one scholars from Canada, USA, the UK, Germany, Australia, the Netherlands, and the Czech Republic attended the workshop. In their presentations they focused on different aspects of these forms of so-called "contentious politics" (McAdam, Tarrow, \& Tilly, 2001). These participants came from a variety of disciplines such as anthropology, comparative literature, political science, education, and sociology, and all have grappled with various questions concerning this recent wave of protests. This special issue contains four articles presented at the workshop, with more to come in a forthcoming issue focusing on austerity measures and labour movements.

The four articles included in this issue explore a number of issues debated at the workshop. Foran discusses the recent transformations of political cultures of opposition that fomented $20^{\text {th }}$ century social and anti-colonial revolutions. He points out that the $21^{\text {st }}$ century non-violent radical movements illustrate the virtues of "prefigurative politics" or the politics that shifts away from the goals of state control toward the construction of alternative visions for a more socially just society (also discussed by Alex Khasnabish in this issue) and horizontalist (as opposed to hierarchical) ways of action (or what Funke calls "rhizomatic" movement logic in this issue). Foran calls the emergent 
political cultures "political cultures of creation", (In this issue Khasnabish discusses one specific way these cultures are forged.) Foran further compares three paths to bringing about social and political change: (1) the electoral challenge to state power as exemplified by the electoral victories of the leftof- centre parties in some Latin American countries; (2) the establishment of autonomous spaces both below the state at the community level (e.g. the Zapatistas and Occupy) or above it at the global level (e.g. the Global Justice Movement); and (3) the path that evolves from massive non-violent direct action to a protracted struggle for democracy (e.g. the Arab Spring). He distinguishes all these forms of political activism from the earlier struggles, focusing on the political cultures that gave impetus to each of them. $\mathrm{He}$ proposes that the future of radical social change may result from various intersections of deeply democratic social movements and diverse new parties and political coalitions inspired by political cultures of creation as well as opposition.

Starting with the premise that all political mobilizations require effort to build cooperation and linkages among activists, Funke's article examines movement-building dynamics by introducing the notion of "movementbuilding relays." He asserts that current-day struggles are characterized by the "rhizomatic movement logic" that thrives on multiplicity which lacks a central actor, issue, strategy or ideology beyond opposition to neoliberalism and demands for "real" democracy. This rhizomatic movement logic, according to Funke, allows for considerable diversity and the multiplicity of struggles and visions while bringing together diverse loosely linked organizations, groups and movements. Yet, these diverse "multitudes" congregate and network at demonstrations, forums or Occupy-type protests, suggesting patterns of interactions and mechanisms for collaboration. By focusing on the milieu, the (infra)structure or environment in which groups and activists engage and seek linkages and cooperation, or what he calls "movement-building relays," Funke explores movement-building dynamics and cooperation outcomes between multiple groups or networks. He also contends that the dominant rhizomatic movement logic affects both the ability to cooperate and the relay activities. He concludes that, due to its rhizomatic nature, current activists are not likely to articulate commonalities and convergences. The result is a "politics that is often unable to move beyond mere symbolic acts, re-active resistances and loose networking rather than towards a politics of organizing for concrete and long-term movement building" (p. 41).

Khasnabish presents an insightful, introspective discussion of the role of politically engaged social science research in articulating radical imaginaries that inspire and impel social justice struggles. His discusses the Halifax Radical Imagination Project grounded in ethnography and participant-action research and its efforts to convoke radical thinkers in Halifax and beyond. As co-founders of this project, Khasnabish and his colleague mobilized their positions and resources as academic researchers in an effort to further stimulate and articulate knowledge production that various community activists were already engaged in with uneven levels of commitment and 
success. Khasnabish calls for critical research that, in addition to identifying structures and expressions of violence, exploitation and oppression and movements' responses to these injustices, would "participate in facilitating collective, grassroots ways of envisioning and, ultimately, materializing alternatives to systemic forms of oppression and exploitation" (p. 62).

Finally, Barnartt questions whether recent protests organized by people with disabilities in Egypt are linked to Egypt's 2011 pro-democracy protests. Demonstrating that disability protests happened during and after the prodemocracy movements and in close physical proximity to them, she suggests that the language of "rights" articulated by the pro-democracy protests might have spread to the disability protests, although Egypt's adoption of the UN Convention on the Rights of Persons with Disabilities might have contributed to this development as well. In exploring the relationship between the two movements, Barnartt presents an example of the "movement spillover." Drawing on Meyer and Whittier's (1994, p. 290) definition of the social movement spillover as a process through which ideas, tactics, and styles of one movement affect other social movements (1994, p. 290), Funke (this volume) identifies the "movement spillover" as one mechanism through which different activists cooperate and establish linkages. By examining the rights discourses of the two movements in Egypt, as covered in Englishlanguage media, Barnartt contributes to this discussion.

\section{References}

Buechler, S. M. (2000). Social movements in advanced capitalism. New York: Oxford University Press.

Hardt, M., \& Negri, A. (2005) Multitude: War And Democracy In The Age Of Empire., Penguin.

McAdam, D., McCarthy, J. D., \& Zald, M, Y. (Eds). (1999). Comparative perspectives on social movements. Political opportunities, mobilizing structures, and cultural framings (Cambridge studies in comparative politics), Cambridge.

McAdam, D., Tarrow, S. \& Tilly, C. (2001). Dynamics of contention. Cambridge and New York: Cambridge University Press.

Melucci, A. (1989). Nomads of the present: Social movements and individual needs in contemporary society. New York: Random House.

Meyer, D., \& Whittier, N. (1994). Social movement spillover, Social Problems, 41(2), 277-298.

Routledge, P., \& Cumbers, A. (2009). Global justice networks: Geographies of transnational solidarity. Manchester and New York: Manchester University Press.

Smith, J. (2008). Social movements for global democracy. Baltimore, MD: Johns Hopkins University Press.

Smith, J., \& Johnston, H. (Eds.). (2002). Globalization and resistance: Transnational dimensions of Social Movements. Boulder, CO: Rowman \& Littlefield.

Smith, M., (Ed.). (2008). Group politics and social movements in Canada. Toronto: Broadview Press.

Snow, D.A., \& Benford, R. D. (2000). Framing processes and social movements: An overview and assessment. Annual Review of Sociology 26: 611-39.

Tarrow, S. (2005). The new transnational activism. New York, NY: Cambridge University Press. 